\title{
ТРАНСФОРМАЦИЯ КАТЕГОРИИ КАЧЕСТВО ЖИЗНИ НАСЕЛЕНИЯ В ПЕРИОД ПАНДЕМИИ COVID-19
}

\author{
() 2021 Фахрутдинова Елена Валерьевна \\ доктор экономических наук, профессор \\ Казанский (Приволжский) федеральный университет, Россия, Казань \\ E-mail: efahr@mail.ru
}

В статье исследовано влияние пандемии COVID-19 на качество жизни населения. Категория качества жизни населения дополнена новыми элементами, которые проанализированы. Рассмотрена динамика развития элементов качества жизни населения и выявлены его новые элементы. Проанализированы показатели здоровья населения и рынка труда с начала 2020 года, т.е. с момента начала пандемии COVID-19.

Ключевые слова: качество жизни населения, пандемия, COVID-19, элементы качества жизни, человеческий капитал, коронавирусная инфекция.

С начала 2020 года мир изменился и стал жить в условиях новой реальности - с неизвестным ранее коронавирусным заболеванием (COVID-19), которое повлекло за собой возникновение пандемии и, как следствие, изменение всех сфер жизни общества, трансформацию привычных устоев и сложившихся социально-экономических отношений. Глобальный вызов, связанный с возникновением новой коронавирусной инфекции, которая распространялась вне зависимости от границ государств мира и оказала огромное влияние на все сферы жизнедеятельности страны: экономическую и политическую, социальную и культурную, а также продолжается по настоящее время. Категория качества жизни населения тоже претерпела изменения.

В нашей более ранней работе мы отмечали [11, с. 110], что в 2004 г. Президент России впервые определил качество жизни, как целевой критерий социально-экономического развития России [10]. С этого времени проблема измерения и оценки качества жизни населения России перешла в плоскость решения практических задач. Уже в июне 2004 г. Минфин России и Минэкономразвития России выпустили «Методические рекомендации по подготовке докладов о результатах и основных направлениях деятельности субъектов бюджетного планирования», в которых была представлена первая официальная номенклатура показателей качества жизни населения [5]. Но она не в полной мере отражала разные аспекты жизнедеятельности людей и не была обеспечена соответствующей методикой. Кроме того, не имелось данных о примене- нии названной номенклатуры на практике.

Так же нами отмечено [11], что в последующие годы в выступлениях первых лиц государства неоднократно подчёркивалась важность ориентации социально-экономической политики на повышение качества жизни населения, ставилась задача поиска таких направлений деятельности, которые изменили бы качество жизни в России, обеспечили бы нашей стране лидерские позиции [2].

Инвестиции в человеческий капитал определены Президентом РФ Путиным В.В. как вектор развития России [4]. По нашему мнению, категории «человеческий капитал» и «качество жизни населения» взаимосвязаны между собой и предопределяют друг друга. Чем выше качество жизни населения, тем выше качество человеческого капитала и тем быстрее он развивается и наоборот.

В наших более ранних исследованиях при изучении работ российских и зарубежных ученых в области управления качеством жизни выявлено относительное единство взглядов исследователей в общем видении качества жизни. Многие ученые сходятся во мнении, что качество жизни является обобщающей социально-экономической категорией, включает в себя не только уровень потребления материальных благ и услуг, но и удовлетворение духовных потребностей, состояние здоровья, продолжительность жизни, условия окружающей среды, морально-психологический климат, душевный комфорт человека. $[11$, c. 20].

В научной литературе (например, у Слезингера Г. Э) качество жизни населения включает 
в себя следующие элементы:

- качество образования,

- качество здоровья,

- качество питания,

- качество жилища,

- качество окружающей среды,

- качество благоустройства жизни,

- качество правовой защиты,

- качество социальной защиты,

- качество рекреации [7, с. 10].

Мы считаем необходимым включить еще несколько неотъемлемых элементов качества жизни населения - качество трудовой жизни и качество социального взаимодействия, которые претерпели наибольшую трансформацию в период пандемии COVID-19. Также наибольшее изменение в связи с пандемией COVID-19 произошло с качеством здоровья населения. Показатели качества жизни населения и развитие его элементов в их тесном взаимодействии и взаимообусловленности позволяют оценить уровень социального развития общества в целом.

Рассмотрим более подробно три элемента качества жизни населения, наиболее подверженных изменениям в связи с пандемией COVID-19: качество здоровья населения, качество трудовой жизни и качество социального взаимодействия.

Качество здоровья населения (см. табл. 1). По состоянию на 01.01.20 г. данные о новых случаях в доступных источниках не публиковались. 27 пациентов проходят лечение в госпиталях Wuhan Jinyintan Hospital и Tongji Hospital. Рынок морепродуктов (в Jianghan district), где работало большинство больных, с 1 января 2019 г. закрыт для посещения, проводятся дезинфекционные мероприятия. По словам работников рынка, пациенты с жаром и кашлем были госпитализированы за неделю до сообщений в СМИ о вспышке [1].
Качество трудовой жизни населения. Основная трансформация в качестве трудовой жизни произошла в изменении условий работы - переходе на удаленную работу, что повлекло за собой изменение трудового законодательства, структуры офисного фонда и снижение издержек работодателя.

Основные статистические данные удалённой работы на 2021 год [8]:

- удаленные работодатели могут сэкономить в среднем 11000 долларов на надомного работника, занятого неполный рабочий день;

- 74\% удаленных сотрудников зарабатывают менее 100000 долларов в год;

- Заработная плата удаленных сотрудников превышает 100 тыс. Долларов в год в 2,2 раза чаще, чем на местах;

- $80 \%$ людей говорят, что их компании не будут платить за Интернет, если они будут работать удаленно;

- $72 \%$ компаний также не оплачивают коворкинг и звонки по мобильному телефону удаленных сотрудников;

- 78\% работников согласились бы на сокращение заработной платы на $5 \%$ или более, чтобы работать удаленно «хотя бы часть времени», при этом $20 \%$ готовы снизить зарплату более чем на $10 \%$;

- средняя компания с 1000 сотрудников может сэкономить около 11 миллионов долларов в год [8].

Основные статистические данные удалённой работы на 2021 год [9]:

- $16 \%$ компаний в мире работают полностью на удалённой работе;

- $44 \%$ компаний категорически не разрешают удалённую работу;

- основная причина, по которой люди пред-

Таблица 1. Динамика роста заболеваний COVID-19 и новых смертей в мире

\begin{tabular}{|c|c|c|}
\hline Дата & Количество случаев, всего в мире & Прирост новых смертей, в \% \\
\hline 01.01 .2020 & 27 & Не известно \\
\hline 01.04 .2020 & 857442 & $4,9 \%$ \\
\hline 01.07 .2020 & 10466465 & $1,15 \%$ \\
\hline 01.10 .2020 & 33866783 & $0,62 \%$ \\
\hline 01.01 .2021 & 83404649 & Нет данных \\
\hline 01.04 .2021 & 128815808 & Нет данных \\
\hline 01.07 .2021 & 22594229 & $0,78 \%$ \\
\hline 01.10 .2021 & 233789229 & $0,21 \%$ \\
\hline
\end{tabular}

Источник: составлено автором на основе данных https://www.rospotrebnadzor.ru/region/korono_virus/epid. php 
почитают работать удалённо - улучшение баланса между работой и личной жизнью;

- $77 \%$ сотрудников говорят, что они более продуктивны работая дома;

- средний годовой доход удалённых сотрудников выше, чем у прочих сотрудников;

- $85 \%$ опрошенных руководителей считают, что команды с удалёнными сотрудниками станут новой нормой;

- $74 \%$ работников говорят, что возможность работать удалённо снизит вероятность их ухода из компании;

- три самые большие проблемы, связанные с удалённой работой: отключение от сети после работы (22\%); одиночество (19\%); коммуникации с коллегами (17\%) [9].

По данным Минтруда России на 1 квартал 2021 года В России удаленно продолжают работать больше 3 млн человек, в начале 2020 года, до начала пандемии так работало около 30000 человек, сообщил в Госдуме замминистра труда и соцзащиты Андрей Пудов. 9 февраля в министерстве отмечали, что удаленно работают 3,57 млн россиян и что это на $3,5 \%$ меньше, чем в январе. В начале года дистанционно работали 3,7 млн трудящихся [6].

Качество социального взаимодействия. Переход на удаленную работу, риск заражения коронавирусной инфекцией, принятые государствами ограничительные меры в связи с опасной санитарно-эпидемиологической ситуацией, объявленный локдаун повлекли за собой нарушение социальных связей и разрушение привычного социального взаимодействия.

Пандемия COVID-19 ухудшила положение бездомных людей во всем мире. В наименее развитых странах остро встала проблема продовольствия для наименее защищенных слоев населения, которую необходимо было решить правительствам этих стран. Также проблемой для многих стран стал рост безработицы, соответственно государствам необходимы меры по поддержке занятости. По оценкам МОТ, в мировом масштабе число людей, которые попол- нят ряды работающих малоимущих, составит т 8,8 до 35 млн. При этом изначально прогнозировалось, что в 2020 г. этот показатель, наоборот, снизится на 14 млн. [3].

Также следует отметить, что применяемые правительствами многих стран меры по предотвращению распространения коронавирусной инфекции ухудшают положение уязвимых групп населения, что является противоречием институционального регулирования и требует разрешения в виде отдельных мер государственной поддержки этих слоев населения.

Отдельного внимания заслуживает психологическая помощь населению в условиях самоизоляции и введенных ограничений, особенно группам риска по бытовому насилию в семье, людям с ограниченными возможностями и пожилым людям. Для пожилых людей остро стоит проблема продовольственной безопасности и цифрового разрыва, который проявляется в отсутствии навыков у пожилого поколения по работе с новыми гаджетами и технологиями, что ограничивает их в доступе к информации и усиливает негативные последствия самоизоляции. Для людей с ограниченными возможностями остро стоит проблема доступа к медицинской помощи в условиях пандемии. Меры по профилактике распространения коронавирусной инфекции (частое мытье рук, обработка поверхностей, уборка помещений, ношение масок и перчаток) могут быть не доступны людям с ограниченными возможностями в силу физических ограничений.

С другой стороны, есть положительные моменты влияния пандемии COVID-19 на качество жизни населения и развитие человеческого капитала. К ним мы относим: развитие сферы культуры, рынка образовательных услуг и рынка труда, инклюзивной среды, онлайн-торговли и его доступности всех видов услуг. Следует отметить, что дистанционный режим работы способствует созданию инклюзивной среды, где дискриминация в рабочей среде минимизирована и обеспечивается безопасное рабочее пространство.

\section{Библиографический список}

1. Актуальная эпидемическая ситуация в России и в мире // Режим доступа URL: https://www.rospotrebnadzor. ru/region/korono_virus/epid. php свободный (дата обращения 15.10.2021)

2. Волкова М., Кузьмин В., Латухина К. Президент сказал свое слово. Нам предстоит стать обществом умных, свободных и ответственных людей // RG. RU: электр. версия газеты «Российская газета» Федеральный выпуск № 5038 (214). 2009. 13. нояб. Режим доступа URL: http://www.rg.ru/2009/11/13/poslanie. html (дата обращения: 16.11.2009). 
3. Дайджест. Социальные последствия пандемии COVID-19 и инклюзивность // Режим доступа URL: https:// ach.gov.ru/upload/pdf/Covid-19-inclusion. pdf свободный (дата обращения 07.10.2021)

4. Как и зачем власти собираются умножать человеческий капитал// Ведомости от 23.05.2018/Режим доступа URL: https://www.vedomosti.ru/economics/articles/2018/05/24/770536-umnozhat-chelovecheskii-kapital свободный, (дата обращения 15.09.2021)

5. Методические рекомендации по подготовке Докладов результатов и основных направлениях деятельности субъектов бюджетного планирования // RG. RU: электр. версия газеты «Российская Газета-Бизнес» № 464. 2004. 22. июн. Режим доступа URL: http://www.rg.ru/gazeta/biznes/2004/06/22. html (дата обращения: 10.06.2008).

6. Минтруд оценил количество «удаленщиков» в России в 3 млн человек// Режим доступа URL: https:// www.interfax.ru/russia/757540 свободный (дата обращения 07.09.2021).

7. Слезингер Г. Э. Социальная экономика. М.: Дело и Сервис, 2001. -368c.

8. Статистикаудаленной работы в 2020году//Режимдоступа URL:https://webcache.googleusercontent.com/searc h?q=cache:366UBtVdTKUJ:https:/ichi.pro/ru/statistika-udalennoj-raboty-v-2020-godu-213033806944514+\&cd $=10 \& \mathrm{hl}=\mathrm{ru} \& \mathrm{ct}=\mathrm{clnk} \& \mathrm{gl}=\mathrm{ru} \& \mathrm{client}=\mathrm{safari}$ свободный (дата обращения 11.10.2021).

9. Полная статистика по удалённой работе за 2021 год// Режим доступа URL: https:// promopoisk.com/articles/polnaya-statistika-po-udalyonnoy-rabote-za-2021-god свободный (дата обращения 15.10.2021)

10. Путин В. Выступление на встрече с членами Правительства, руководством Федерального Собрания и членами Президиума Гос. совета // Официальный сайт Президента РФ. 2005. 05. сен. Режим доступа URL: http://www.kremlin.ru/text/appears/2005/09/93296. shtml (дата обращения: 17.03.2008).

11. Фахрутдинова Е.В. Качество жизни населения в системе социально-экономических отношений (институциональный подход)// диссертация на соискание ученой степени доктора экономических наук/Казанский финансово-экономических институт. Казань, 2010. - 420с. 